\title{
Viktor Emil Frankl
}

\author{
Prathyusha Manchala
}

Postgraduate, Dept. of Psychiatry, Institute of Mental Health, Osmania Medical College, Hyderabad, Telangana, India

*Corresponding Author: Prathyusha Manchala

Email: prathyusha.manchala@gmail.com

\begin{abstract}
Viktor Emil Frankl was an Austrian Neurologist and Psychiatrist. He worked from the frame work of existential therapy. During world war II, he was under Nazi captivity, it is this experience that shaped his work and development of Logotherapy. It is considered the "Third Viennese school of Psychotherapy" with Freud's psychoanalysis as first and Adler's individual psychology as second Viennese school of psychotherapy. After the camps were liberated, in 1946, he published his world famous book - 'Man's Search for Meaning' outlining his experiences in the concentration camp as well as the basic tenets and techniques of logotherapy. Frankl became one of the key figures in existential therapy and a prominent source of inspiration for humanistic psychologists.
\end{abstract}

Keywords: Viktor Frankl, Logotherapy, Existential therapy.

\section{Introduction}

Witness of the twentieth century, symbol for incomprehensible survival in Nazi concentration camps, proponent of third Viennese school of psychotherapy-all of this is Viktor E Frankl, born in Vienna in 1905 to a Jewish family of civil servants. ${ }^{1}$

His interest in psychology surfaced early. For the final exam in his school, he wrote a paper on psychology of philosophical thinking. He studied medicine at University of Vienna. From 1933-1937 he completed his residency in Neurology and Psychiatry at Steinhof psychiatric hospital in Vienna. ${ }^{1}$

From 1942-1945, he spent three years in various camps .He was first deported to the Theresienstadt ghetto. His psychiatric skills were noticed and was assigned to a psychiatric care ward. He helped new comers to overcome shock and grief. In 1944, he and his wife Tilly were transported to Auschwitz camp. Next year he was offered to be moved to the rest camp Turkheim which was later liberated by American soldiers. All of his family members died by this time. After being liberated, he returned to Vienna and wrote Man's Search for Meaning. He described the life of an ordinary concentration camp inmate from the objective perspective of a psychiatrist. It also contained the tenets of logo therapy. He died on $2^{\text {nd }}$ September, 1997 of heart failure. ${ }^{1}$

\section{Anecdotes from his Life}

Frankl often described his mother as kindhearted and deeply pious, while his father's philosophy was Spartan. He had a strong sense of duty with principles and he remained faithful to them. Viktor once took Rorschach inkblot test at an Innsbruck psychiatric clinic. The Psychologist had commented that he had never seen such a range between rationality and deep emotions. Viktor attributes the former to his father and the latter to his mother. ${ }^{1}$

In another instance, Viktor's perspective on the death of his father showed his quality of enduring pain without breaking down. When his father was dying from pulmonary edema in the camp, Viktor injected morphine to alleviate his pain, kissed him and left. He knew he wouldn't see him alive again. Yet, he had the most wonderful feeling one could imagine as he had accompanied his father to the threshold and had spared him the unnecessary agony of death. ${ }^{1}$

Frankl concluded that even in the most absurd and painful situations, life has potential meaning and therefore, even suffering is meaningful. An example of this idea is found in his account of an experience he had while in camp:

"We stumbled on in the darkness, over big stones and through large puddles. Hardly a word was spoken, the icy wind didn't encourage talk. The man marching next to me whispered: "If our wives could see us now! I do hope they are better off in their camps and don't know what is happening to us. That brought thoughts of my own wife to mind. Occasionally I looked at the sky where the stars were fading and the pink light of the morning was beginning to spread behind a dark bank of clouds. I heard my wife answering me, saw her smile, her frank and encouraging look. Real or not, her look was then more luminous than the sun which was beginning to rise. The truth - which love is the ultimate and the highest goal to which man can aspire. I understood how a man who has nothing left in this world still may know bliss, be it only for a brief moment, in the contemplation of his beloved." 2

\section{Analysis of Camp Experiences from Objective Perspective}

In the book, he explained three phases of the inmate's mental reactions to camp's life: the period following his admission, the period when he is well entrenched in camp routine and the period following his release. The symptom that characterizes the first phase is shock.

During the second stage, it is apathy, the blunting of emotions which eventually makes him insensitive to daily sufferings.

The third stage after liberation is that of depersonalization, bitterness and disillusionment. He called it the psychological counterpart of bends. Just as the physical health of the caisson worker would be endangered if he ascended suddenly, so also the man who has suddenly been 
liberated from mental pressure can suffer damage to his moral and spiritual health. ${ }^{3}$

\section{Logotherapy}

Frankl believed that lack of meaning is the paramount existential stress. Search for meaning in life is identified as the primary motivational force in human beings. ${ }^{4}$

His approach is based on three concepts:

1. Freedom of will

2. Will to meaning

3. Meaning in life

Freedom of Will: Humans are not fully subject to conditions but are free to decide and are capable of taking their stance towards psychological, biological and social conditions. Freedom here is defined as a space of shaping one's own life within the limits of given possibilities.

This sense of freedom provides the clients with room for autonomous action even in the face of trauma. This enables them to cope with symptoms and regain control over self. ${ }^{4}$

Will to Meaning: Humans are not only free, but most importantly, they are free to achieve goals and purposes. This search for meaning is seen as the primary motivation of humans. When this is lacking, humans experience an abysm of emptiness which in turn gives rise to aggression, depression and suicidality.

Logotherapist assists clients in the realization of those meaning possibilities themselves. However the therapist doesn't actively offer any specific meanings to life. ${ }^{4}$

Meaning in Life: Meaning potentials, although objective in nature are linked to specific situations and persons and are therefore continually changing. Thus logo therapy doesn't declare or offer some general meaning of life. Rather clients are aided in achieving flexibility that will enable them to shape their day to day lives in a meaningful manner. ${ }^{4}$

\section{Therapeutic Thechniques}

Paradoxical Intention: Clients learn to overcome their anxiety by self-distancing and humorous exaggeration, thus breaking the vicious circle of symptom and symptom amplification. ${ }^{3}$

Dereflexion: Instinctive processes are impeded and hindered by exaggerated self-observation. This way, some wellfounded sensations of anxiousness or sadness will be increased by self-observation. To break this neuroticising circle by drawing patient's attention away from the symptom is the purpose of dereflexion.

Socratic Dialogue/Modification of Attitudes: It is a conversational method in which specific questions are aimed to raise into consciousness and the possibility to find, freedom to fulfill meaning in one's life. ${ }^{4}$

\section{Achievements of Frankl}

In 1924, he became president of Sozialistische Mittelschuler Osterreich, a social democratic youth movement for high school students of Austria. ${ }^{1}$

He offered a programme to counsel high school students from 1928-1930. After this, there wasn't a single student who committed suicide. This grabbed the attention of Wilhelm Reich who invited him to Berlin. ${ }^{5}$

In 1940, while working at Rothschild hospital, he deliberately gave a wrong diagnoses to save several patients from Nazi euthanasia programme. From 1946-1971, he ran the Vienna polyclinic of Neurology. ${ }^{5}$ In 1948, he earned a $\mathrm{PhD}$ in philosophy. ${ }^{1}$ In 1955 , he was awarded a professorship of Neurology and Psychiatry at the University of Vienna, He resided at Harvard University(1961), and at Duquesne University, Pittsburgh(1972). ${ }^{4}$

He won numerous awards like the Cardinal Innitzer prize, Austria in 1962, Austrian cross of honour for science and art in 1969 and the Oskar Pfister Award. Given by American Psychiatric Association for important contributions to religion and psychiatry in $1985 .{ }^{4}$

\section{Contributions}

His works in English are:

1. Man's search for meaning.

2. The doctor and the soul.

3. The will to meaning.

4. Viktor Frankl recollections: An autobiography.

5. Man's search for ultimate meaning.

6. The unconscious god was his dissertation. It is an account of examination of the relation of psychology and religion.

Overall, Frankl had published more than 30 books, which have been translated to 40 languages.

\section{Criticism}

Rollo May argued that logo therapy is, in essence, authoritarian. He suggested that it presents a plain solution to all life's problems, which undermines the complexity of human life itself. He also said that, Frankl would provide a goal himself if the patient couldn't find one. This in turn negates patient's personal responsibility, thus diminishing the patient as a person. ${ }^{6}$

Critical views on his life assume that Frankl's religious background guided his conception of meaning within the boundaries of the person and that his theory is founded on his worldview.

\section{Quotes by him}

Frankl once said: "Freedom, however is not the last word. Freedom is only part of the story and half the truth. Freedom is but the negative aspect of the whole phenomenon whose positive aspect is responsibleness.Infact freedom is in danger of degenerating into mere arbitrariness unless it is lived in terms of responsibleness. That is why I recommend that the statue of liberty on east coast be supplemented by statue of responsibility on the west coast".

He also said, in various instances: "Don't aim at success. The more you aim at it, the more you're going to miss it. For success, like happiness, cannot be pursued; it must ensue, and it only does so as the unintended side effect of one's personal dedication to a cause greater than oneself." 7 
"No man should judge unless he asks himself in absolute honesty whether in a similar situation he might not have done the same." 7
"Everything can be taken from a man but one thing, the last of the human freedoms- to choose one's attitude in any given set of circumstances, to choose one's own way."7

\section{Table 1: Major achievements of Frankl}

\begin{tabular}{|l|l|}
\hline Year & Achievement \\
\hline 1924 & President of social democratic youth movement for high school students in Austria. \\
\hline 1925 & Doctorate in medicine, University of Vienna. \\
\hline $1933-1937$ & Completed residency in Neurology and Psychiatry at Steinhof psychiatric hospital, Vienna. \\
\hline 1940 & Started working at Rothschild hospital, headed Neurology department. \\
\hline 1946 & Ran Vienna polyclinic of Neurology, Published his world famous book -'Man's search for Meaning.' \\
\hline 1948 & $\begin{array}{l}\text { Earned a Ph. D. in philosophy with a dissertation - 'The Unconscious God' which examined the relation } \\
\text { between psychology and neurology. }\end{array}$ \\
\hline 1955 & Published his book 'The Doctor and the Soul.' \\
\hline 1967 & Published 'Psychotherapy and existentialism: selected papers on logotherapy.'’ \\
\hline 1969 & Austrian cross of Honour for Science and Art \\
\hline 1985 & Oskar pfister award, USA. \\
\hline 1988 & Great silver medal with star for services to republic of Austria. \\
\hline 1995 & Great gold medal with star for services to republic of Austria. \\
\hline
\end{tabular}

\section{The Present Fate of Logotherapy}

Since logo therapy is a simple therapy that focuses on a person's will to meaning, it can be integrated into modern psychological treatments. It has been used to improve the quality of life of adolescents with terminal cancer. It has also been advocated as a treatment for trauma. It is also used in positive psychology context to help people with no discernible mental illnesses to live a life with meaning, and in turn achieve higher levels of wellbeing.

Recent psychological commentaries have claimed that meaning centered interventions such as logo therapy are of prime importance to human condition, with applicability to contexts such as disaster psychology, addiction issues, and depression and anxiety issues. Recently, it has been shown that a lack of meaning can lead to boredom, indicating that logo therapy could be an effective intervention for someone who is often bored.

\section{Conclusion}

Frankl's surprising resilience amidst his experiences of extreme suffering and sadness speaks on how his theories may have helped him and those around him. His contribution in the form of logo therapy is invaluable in the current scenario, where the number of suicides among all age groups and all walks of life has seen an alarming rise.

\section{Acknowledgement}

I would like to thank Dr. Sireesha Srinivas Rao, Professor of Psychiatry, Institute of Mental Health, Hyderabad for encouraging me to write and giving valuable suggestions on improving it.
2. Viktor E. Frankl: Man's search for meaning, p 48, Rider publishers:2008.

3. Viktor E Frankl: Man's search for meaning, p 22, p 35, p 95, p 97, Rider publishers:2008.

4. Viktor Frankl Institute Vienna, Available fromhttp://www.univie.ac.at/logotherapy/wp/leben-und-werk/,cited on 25-07-2018.

5. Haddon Klingberg, When Life Calls Out to Us: The Love and Lifework of Viktor and Elly Frankl, Double day publishers, 2001.

6. Rollo May, Existential psychology, Random House publishers, 1969.

7. Viktor E Frankl: Man's search for meaning,p 12,p 58,p 75, Rider publishers:2008.

\section{Conflict of Interest: Nil.}

\section{References}

1. Viktor E. Frankl, Recollections: An Autobiography. Basic Books publishers: 2008. 